УДК 371, 378

Литвинова Світлана Григорівна, начальник методичного центру інформаційних технологій в освіті Управління освіти Оболонського району м. Києва

\title{
ON-LINE НАВЧАЛЬНЕ СЕРЕДОВИЩЕ ВЧИТЕЛЯ-ПРЕДМЕТНИКА ЗАГАЛЬНООСВІТНЬОГО НАВЧАЛЬНОГО ЗАКЛАДУ
}

\begin{abstract}
Анотація
У статті розглянуті нові підходи до формування інформаційно-комунікаційного навчального середовища вчителів-предметників. Проаналізоване поняття On-line інтерактивного навчального середовища, виділені характерні його ознаки, розроблені етапи формування On-line інтерактивного навчального середовища, обгрунтоване місце On-line інтерактивного навчального середовища в системі дистанційного навчання, узагальнені проблеми впровадження On-line інтерактивного навчального середовища в систему загальної середньої освіти. Розглянуто On-line навчальне середовище, яке спрямоване на реалізацію мети і завдань загальноосвітнього навчального закладу. Виокремлені моделі організації навчально-виховного процесу засобами On-line навчання.
\end{abstract}

Ключові слова: складові дистанційної освіти, моделі дистанційної освіти, форми навчання, інформаційно-комунікаційні технології, On-line навчання, навчальне середовище.

Постановка проблеми. Починаючи із середини XX століття, дистанційна освіта стає доступною формою надання освітніх послуг широким верствам населення. Дистанційна освіта виходить за межі одного навчального закладу, розгортається в глобальну всесвітню систему.

Останні досягнення людства, а саме Інтернет, суттєво вплинули на систему освіти України. Задоволення потреб населення в освітянських послугах, усе більше базується на Інтернет-технологіях. За останні роки огляд сайтів, які наповнені конспектами, рефератами, переказами, творами, аналітичними оглядами, готовими контрольними, курсовими i дипломними роботами, $\epsilon$ самим розповсюдженим способом задоволення потреб студентів вищої школи. На жаль, гіпертекстові посилання надають учням загальноосвітніх навчальних закладів максимальну свободу 
в пошуку навчальної інформації, що часто призводить до того, що останній губиться в безкінечних розгалуженнях, відволікається від головної мети випадковими посиланнями. Тому, дистанційне навчання в загальноосвітніх навчальних закладах вимагає запровадження моделі, побудованої на принципі єдності дидактичних i інформаційно-комунікаційних технологій, що ведуть до створення On-line інтерактивного навчального середовища.

Аналіз останніх досліджень та публікацій. Поняття дистанційного навчання досліджувалося відомими вченими у різних напрямках, що відображено у роботах В.Ю. Бикова, Л.В. Васильченко, Ю.О. Жука, Е.С. Полат, В.Н. Солдаткина, А.В. Хуторського, та інш. Однак навчання засобами Інтернет у реальному часі - On-line інтерактивне навчальне середовище досліджене вченими недостатньо.

Мета роботи: проаналізувати систему On-line інтерактивного навчання у загальноосвітніх навчальних закладах та узагальнити основні поняття поняття, розробити модель On-line інтерактивного навчального середовища вчителяпредметника.

Виклад основного матеріалу. Дистанційне навчання базується на трьох складових: технологічній, змістовій і організаційній [1]. Базовими компонентами Online інтерактивного навчального середовища виступають складові дистанційної освіти, але з розподілом змістової складової на дві важливі складові: методичну й інформаційно-комунікаційну (рис. 1).

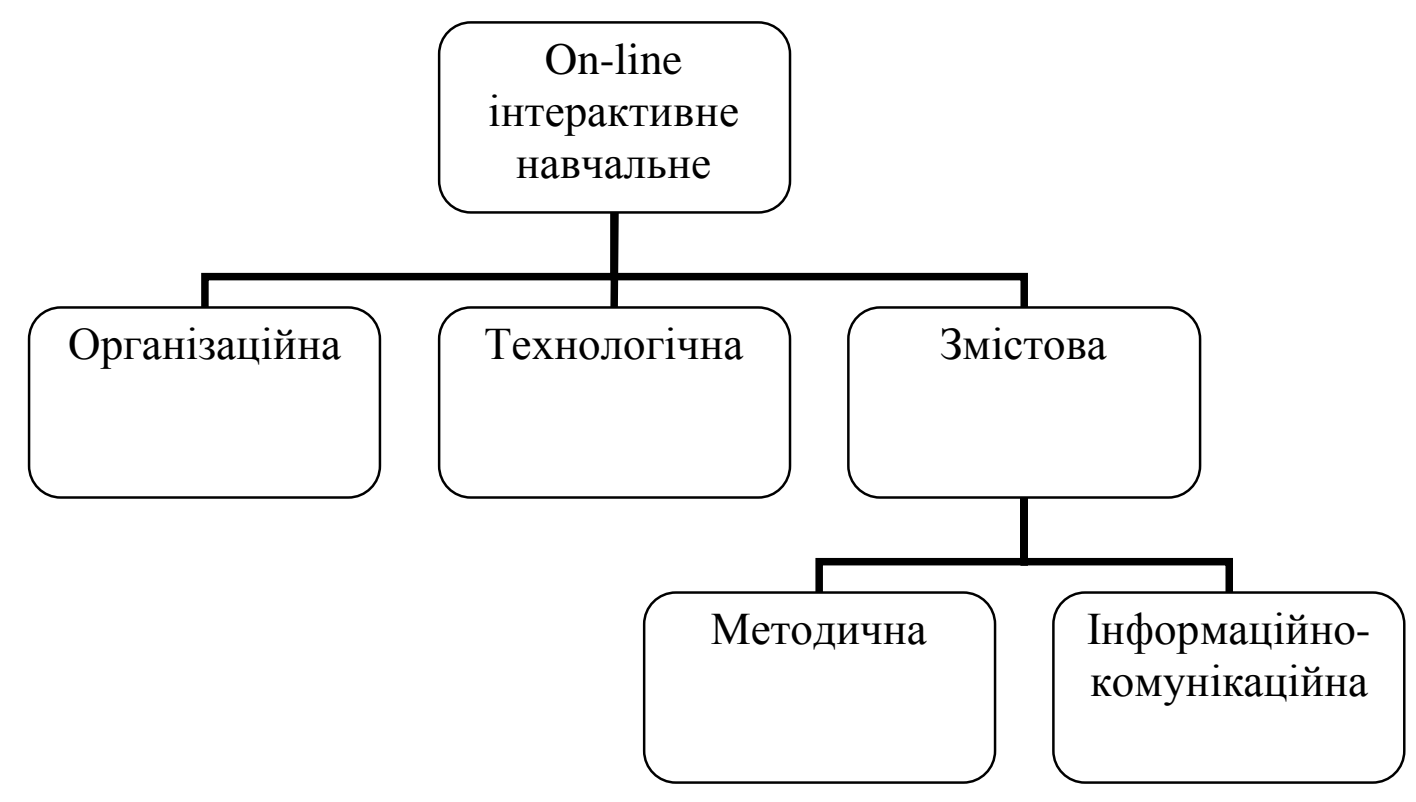

Puc. 1 
Організаційна складова передбачає навчання і перепідготовку викладачів дистанційного навчання, педагогічний супровід учнів у процесі навчання, тобто організацію і проведення навчального процесу. Самою головною ланкою цього ланцюжка є наявність (розробка, створення і підтримка) інформаційних ресурсів.

Технологічна складова не може існувати без відповідної матеріальної бази і програмного забезпечення, що вимагає як одноразових капіталовкладень (комп'ютери, мережі, програмне забезпечення), так і постійних (технічна підтримка, супровід програмного забезпечення, оновлення тощо).

Змістова складова поділяється на методичну й інформаційно-комунікаційну.

Методична складова - створення інформаційних ресурсів у вигляді курсів дистанційного навчання, методична підтримка, розробка наочності, дидактичний супровід.

Інформаційно-комунікаційна складова - створення спеціалізованих сайтів і порталів, навчальних середовищ.

Дистанційна освіта реалізується через притаманні ій комп’ютерно орієнтовані педагогічні технології. На цьому етапі їі розвитку можна виділити основні моделі дистанційної освіти (рис. 2):

Класичні: самостійна робота учнів, відкрита освіта плюс клас, розподілений клас [4].

\section{Модель 1. Самостійна робота учнів}

- Учні працюють самостійно. Ця модель розрахована на вільне переміщення учнів, можливість працювати в асинхронному режимі. Їх забезпечують всім необхідним методичним і навчальним матеріалом, включаючи навчальні програми. Вони мають можливість встановлювати контакт із консультантом школи, який відповідає на запитання, оцінює їхню роботу. Контакти можуть встановлюватися за допомогою телефону, голосової пошти, телеконференції, електронної пошти або звичайної пошти.

Модель 2. Відкрита освіта + клас

- Модель передбачає використання традиційного друкованого матеріалу, інших засобів навчання (відеозаписи, звукозаписи), які повинні забезпечити учню можливість працювати в індивідуальному темпі, використовуючи при цьому у разі потреби інтерактивні телекомунікаційні технології для групової роботи студентів. 
Модель 3. Розподілений клас

- Ц Ця модель будується на організації навчального процесу в режимі реального часу. Заняття ведеться 3 групою учнів очного відділення одночасно 3 «віддаленими» учнями за допомогою інтерактивних телекомунікацій, відеоконференцій. Використання даної моделі припускає, що учні збираються в призначений час перед своїми комп'ютерами або в аудиторії засобами відеоконференцій.

\section{Модифіковані моделі}

Інтеграчія очних і дистанщійних форм навчання:

- це найбільш перспективна модель, як показує вже накопичену практику, причому застосована як до шкільної освіти (профільні курси, використання курсів ДО для поглиблення знань, ліквідації пропусків у знаннях), так і до вузівської;

- $\quad$ інтеграція дистанційного й очного навчання вельми перспективна і в частині ширшого використання учнівського компоненту, навчання за індивідуальними програмами, яке останнім часом усе ширше розповсюджується в наших школах, особливо в старших класах.

Мережеве навчання:

- мережеве навчання необхідне для тих випадків, коли виникають складнощі 3 якісним забезпеченням учнів очними формами навчання (для дітейінвалідів, сільської місцевості, а також для студентів і дорослого населення, охочих підвищити свій професійний рівень, змінити професію тощо). У цьому випадку створюються спеціальні, автономні курси дистанційного навчання 3 окремих навчальних предметів, розділів або тем програми або цілі віртуальні школи, кафедри, університети. 


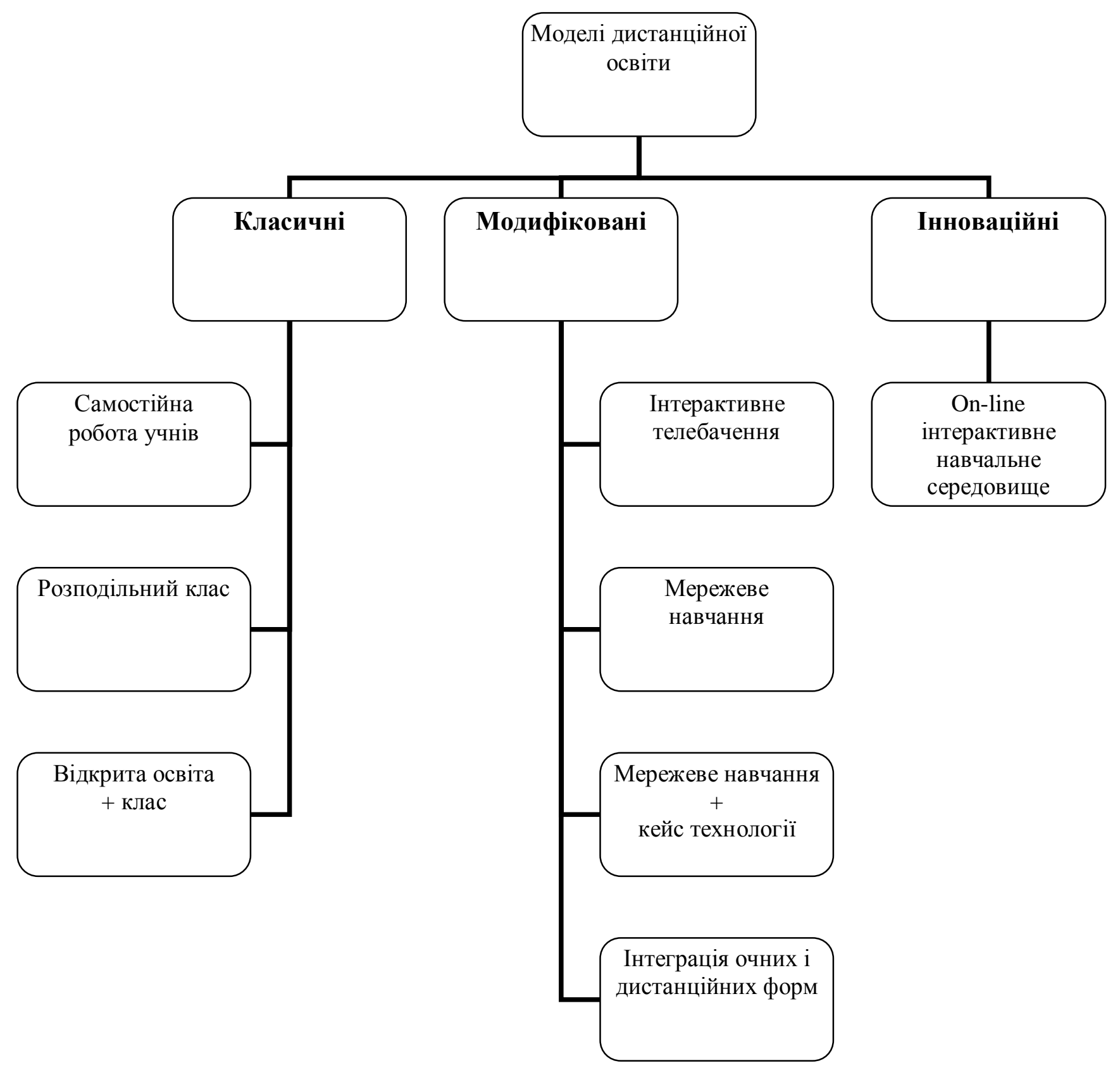

Puc. 2

Мережеве навчання і кейс-технології

- Модель мережевого навчання $\mathrm{i}$ кейс-технологій призначена для диференціації навчання. Набагато ефективніше будувати навчання, спираючись на вже видані підручники і навчальні посібники, за допомогою додаткового матеріалу, що розміщується в мережі, або заглиблювати цей матеріал для просунутих учнів, давати додаткові роз'яснення, вправи для слабких учнів.

Інтерактивне телебачення (Two-way TV)

- Остання модель (інтерактивне телебачення) пов'язана 3 телевізійними технологіями і поки дуже дорога. Це трансляція занять за допомогою відеокамер і телевізійного устаткування на відстань. Це модель розподіленого класу, про яку 
мовилося вище. Час покаже, що виявиться доступнішим, - інтерактивне телебачення або відеоконференції в мережах.

- Ц яодель дистанційного навчання повністю імітує очну форму.

\section{Інноваційні моделі}

\section{On-line інтерактивне навчальне середовище}

- Це навчання в реальному часі з одним або групою учнів, під час якого використовуються web-камери та віртуальна інтерактивна дошка.

- Віртуальний клас розташовано у освітньому навчальному Інтернетсередовищі WIZIQ (Індія).

- $\quad$ WiZiQ надає такі можливості:

- основу даного сервісу складає Flash, що дозволяє легко використовувати всі функції у вікні браузера;

- можливість живого спілкування (аудіо / відео);

- дошка з інтегрованими математичними документами;

- вставка документів (і синхронна (робота) редагування) таких форматів як PowerPoint (зберігає анімацію і переходи), PDF, Flash, MS Word, MS Excel і відео файлів;

- PowerPoint можна використовувати з аудіо і відео вставками.

- Учасники приєднуються до сесії з привілеями:

- можуть розмовляти з іншими;

- малювати і писати на дошці;

- працювати з презентаціями, PDF, Flash файлами і зображеннями;

- учитель із свого боку може відкликати (або призначити) будь-які з вправ. Можна перетворити учнів на пасивних слухачів на час лекції, а потім, повторно призначивши права, дати можливість висловитися;

- учень сам може попросити вчителя призначити ті або інші права. У цьому випадку вчитель натискає один раз на ім'я учасника.

- Можливості для вчителів:

- отримати повноцінну систему для навчання без установки додаткового програмного забезпечення.;

- учитель отримує свій клас без будь-яких додаткових витрат; 
- учитель може планувати сесії за допомогою календаря, для більшої зручності;

- учитель може взаємодіяти з учнями за допомогою дошки, чату, відео і аудіо.

- $\quad$ Заняття можуть бути індивідуальними або груповими.

- $\quad$ Можливості для учнів:

- учні будь-який час можуть знайти вчителів;

- здобути нові знання, знаходячись удома, без установки додаткового програмного забезпечення;

- отримати підручники, презентації уроків і можливість поставити питання фахівцеві;

- пройти тестування;

- побувати на уроці в реальному часі.

Одна 3 моделей організації навчання в On-line інтерактивному навчальному середовищі представлена на рис. 3. Ця модель уможливлює одного вчителя працювати 3 кількома учнями одночасно: проводити опитування, тестування, прослуховувати відповіді, давати можливість (по черзі) кожному учневі писати відповіді на віртуальній інтерактивній дошці, слухати запитання, креслити схеми тощо.

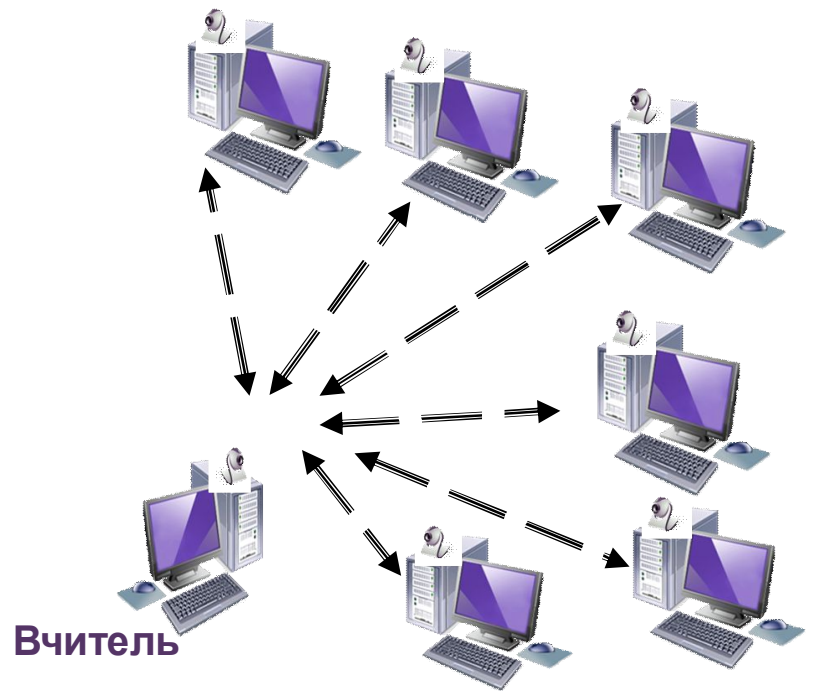

Рис. 3. Модель одночасної транслящуї для декількох учнів

Ми узагальнили можливі організаційні форми навчання:

- $\quad$ один учитель - один учень;

- $\quad$ один учитель - група учнів; 
- $\quad$ група вчителів - група учнів - системний адміністратор.

Інтегровану модель організації On-line навчання представлено на рис. 4.

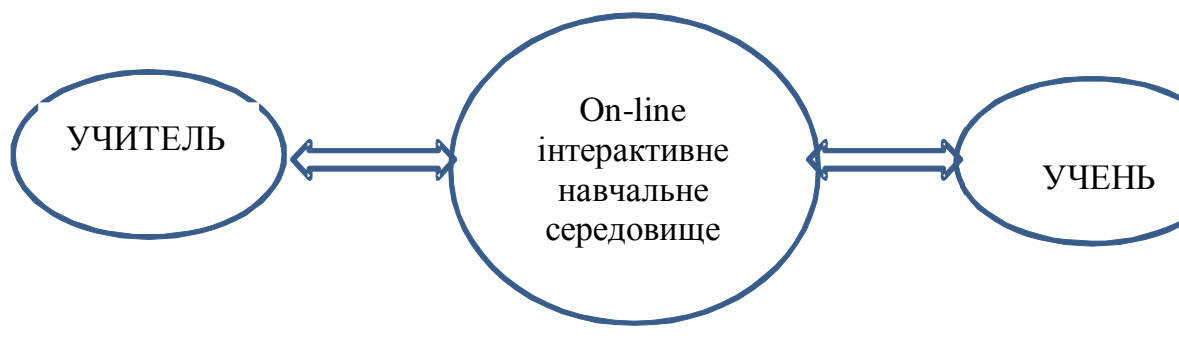

Pис. 4. Інтегрована модель організащіï On-line навчання

Основна форма навчання: On-line навчання.

Характерні ознаки:

- $\quad$ On-line контакт між усіма учасниками навчально-виховного процесу;

- $\quad$ учасники беруть участь у всіх подіях візуально, аудіально кінестетично (за потребою);

• можливість індивідуального спілкування учня з учителем On-line;

- можливість презентації якісної різноманітної навчальної інформації Online;

- можливість індивідуальної роботи учня з навчальною інформацією (за потребою).

Основна діяльність вчителя:

- організація й управління навчально-виховним процесом On-line.

Недоліки:

- неможливість реалізації за відсутності Інтернету;

- $\quad$ можливості апаратних, програмних і мережевих збоїв IKT.

Модель інформаційно-комунікаційного середовища вчителя-предметника в загальноосвітньому навчальному закладі для індивідуального та групового On-line навчання учнів представлено на рис. 5. 


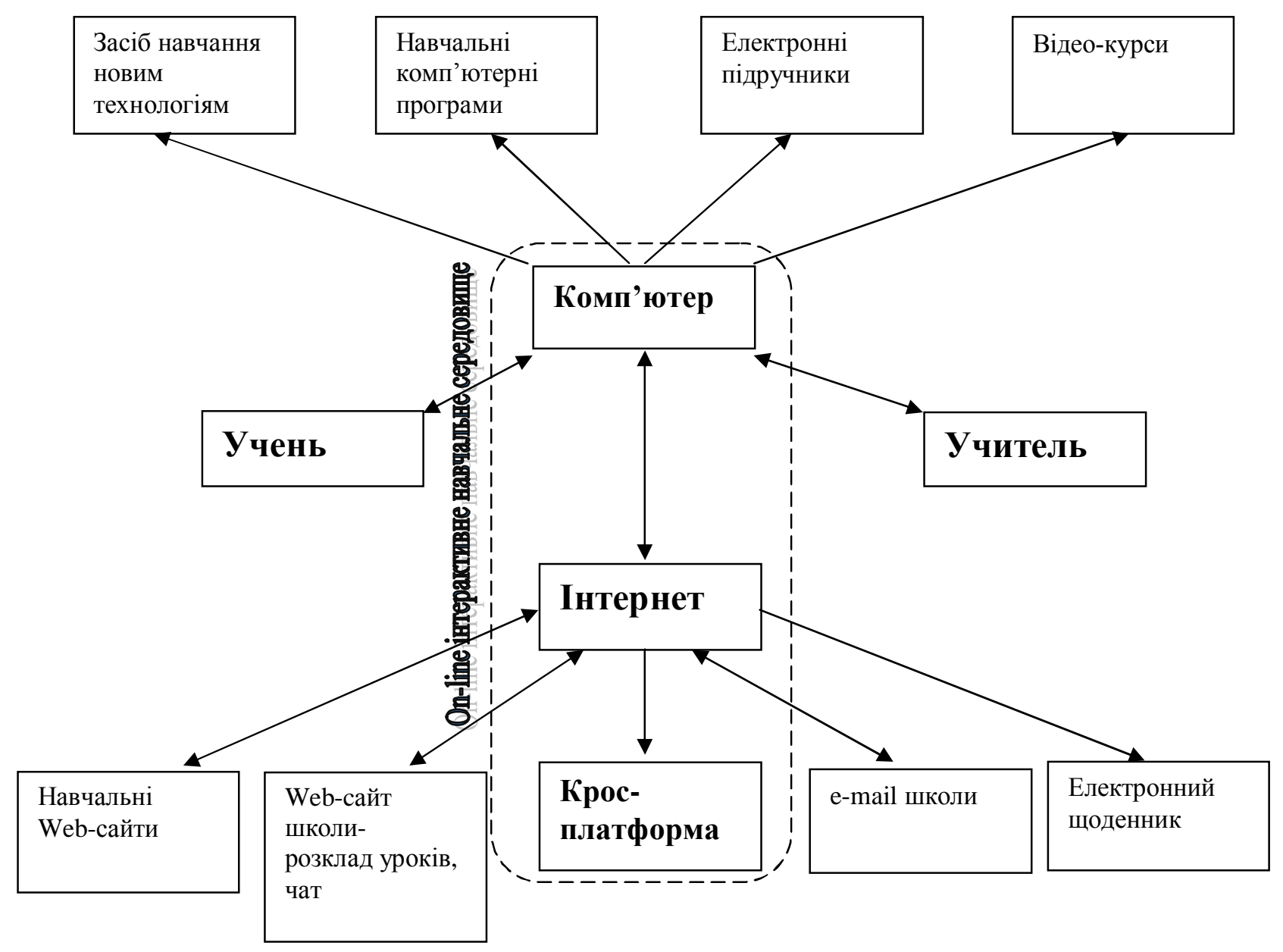


Puc. 5

\section{Етапи формування On-line інтерактивного навчального середовища}

\section{1 етап. Організаційний:}

• $\quad$ створення електронних скриньок для вчителів і учнів;

- $\quad$ діагностика комп'ютерного обладнання в закладі;

- закупівля WEB-камер для вчителів і учнів;

• налагодження і заміна комп'ютерної техніки;

- навчання вчителів;

- $\quad$ навчання учнів;

- $\quad$ проведення пробних On-line уроків.

\section{2 етап. Технологічний:}

- $\quad$ розробка і проведення On-line уроків з математики, англійської мови, природознавства, російської мови, української мови, історії, географії та ін.;

- $\quad$ напрацювання навиків On-line спілкування;

- виявлення й узагальнення помилок під час трансляції уроку;

- $\quad$ відбір найефективніших методів подання матеріалу і контролю знань.

3 eman. Корекційний. Обговорення кожного тренінгу, уроку і планування наступних кроків для поліпшення On-line уроків.

Важливими залишаються методичне і дидактичне забезпечення On-line уроків, a came:

- $\quad$ презентації уроків;

- $\quad$ тестові завдання;

- $\quad$ відеоролики;

- $\quad$ аудіозаписи;

- $\quad$ тексти (Word);

- $\quad$ готові ППП тощо.

Усі ці завдання вчитель розробляє самостійно, і тому потрібно зазначити, що, на жаль, ще й досі :

- $\quad$ відсутні загальнодержавні стандарти володіння IКТ працівниками освіти;

- $\quad$ не створена відповідна матеріально-технічна база в закладах освіти; 
- існує невідповідність між потребами у знаннях i можливостями забезпечення цих потреб;

• низький рівень інформатизації загальноосвітніх навчальних закладів;

- відсутня державна підтримка у розробці електронних дидактичних матеріалів.

\section{Список використаних джерел}

1. Васильченко Л. В. Дистанційне навчання [Текст]: науково-методичне забезпечення; інформаційний простір навчального закладу / Л. В. Васильченко, В. Л. Шевченко. - Х.: Вид. група «Основа», 2009. - 2008 с.

2. Жук Ю. О. Проблеми формування інформаційного середовища навчального закладу [Текст]/ Ю. О. Жук, О. І. Вольневич; за редакцією В. Ю. Бикова // Засоби і технології єдиного інформаційного освітнього простору: Збірка наукових праць Інститут засобів навчання АПН України. - К.: Атіка, 2004. - С. 147-159.

3. Жук Ю. О. Характерні ознаки структури комп’ютерно орієнтованого навчального середовища [Текст]/ Ю. О. Жук, О. М. Соколюк; за ред. В. Ю. Бикова // Інформаційні технології і засоби навчання: Збірник наукових праць Інституту засобів навчання АПН України. -К.: Атіка, 2005. - С. 100-108.

4. Полат E. C. Теория и практика дистанционного обучения [Текст]: учеб. пособие для студ. высш. пед. учебн. заведений / М. Ю. Бухаркина, М. В. Моисеева; ред. Е. С. Полат. - М.: Издательский центр «Академия», 2004. - 416 с.

\section{ON-LINE ОБУЧАЮЩАЯ СРЕДА УЧИТЕЛЯ-ПРЕДМЕТНИКА ОБЩЕОБРАЗОВАТЕЛЬНОЙ ШКОЛЫ}

Литвинова С. Г.

\section{Аннотация}

В работе рассмотрены новые подходы к формированию информационнокоммуникационной общеобразовательной среды для учителей-предметников. Проанализировано понятие On-line интерактивной учебной среды, выделены характерные еe признаки, разработаны этапы формирования On-line интерактивной учебной среды, обосновано место On-line интерактивной учебной среды в системе дистанционного образования, обобщены проблемы внедрения On-line интерактивной учебной среды в систему среднего образования. Рассмотрена On-line обучающая среда, которая направлена на реализацию целей и задач общеобразовательных 
учебных заведений. Обобщены модели организации учебно-воспитательного процесса средствами On-line обучения.

Ключевые слова: компоненты дистанционного обучения, модели дистанционного образования, формы обучения, информационно-коммуникационные технологии, On-line обучение, обучающая среда.

\section{ON-LINE EDUCATIONAL ENVIRONMENT FOR SECONDARY SCHOOL TEACHERS}

\section{Litvinova $S$. \\ Resume}

In the article new approaches to formation of information-communication educational environment for teachers are considered. Concept of On-line interactive educational environment is analyzed, there are determined its characteristics, stages of formation of On-line interactive educational environment are developed, it is proved its place in the system of distance learning as well as problems of its introduction into secondary education system are generalized. Considered training environment is directed on realization of aims and tasks in general educational establishments. Models of the organization of educational process are generalized by means of On-line training.

Keywords: distance learning components, model of distance education, training forms, information and communication technologies, On-line training, training environment. 